Article

\title{
Utilization of Basic Oxygen Furnace Slag in Geopolymeric Coating for Passive Radiative Cooling Application
}

\author{
Chia-Ho $\mathrm{Wu}^{1}{ }^{1}$, Chih-Hong Huang ${ }^{2,3}$, Yeou-Fong $\mathrm{Li}^{3,4}$, Wei-Hao Lee ${ }^{1}$ and Ta-Wui Cheng ${ }^{1,3, * \mathbb{D}}$ \\ 1 Institute of Mineral Resources Engineering, National Taipei University of Technology, Taipei 10608, Taiwan; \\ cep03210@gmail.com (C.-H.W.); glowing955146@gmail.com (W.-H.L.) \\ 2 Department of Architecture, National Taipei University of Technology, Taipei 10608, Taiwan; \\ huangch@ntut.edu.tw \\ 3 Research Center of Energy Conservation for New Generation of Residential, Commercial and \\ Industrial Sectors, National Taipei University of Technology, Taipei 10608, Taiwan; yfli@mail.ntut.edu.tw \\ 4 Department of Civil Engineering, National Taipei University of Technology, Taipei 10608, Taiwan \\ * Correspondence: twcheng@ntut.edu.tw
}

Received: 17 April 2020; Accepted: 9 May 2020; Published: 12 May 2020

\begin{abstract}
Basic oxygen furnace slag (BOFs) is difficult to reutilize because it contains excessive free lime, and thus causes serious expansion. For this reason, how to reuse BOF slag has turned out to be an imperative issue in order to meet the concept of a circular economy. The key intention of this research work is to develop a new way to reutilize BOF slag, which due to its high emissivity in the $8-13 \mu \mathrm{m}$ wavelength range, can be used as a sustainable, passive radiative cooling material. Passive radiative cooling, without the consumption of any energy, achieves the cooling of a surface by reflecting the sunlight and radiating the heat throughout the outer space (not absorbed by the atmosphere). BOF slag is used as a radiative cooling material in geopolymeric coating. This coating possesses an emissivity of 0.95 within the range of $8-13 \mu \mathrm{m}$ and also has high conductivity, but its gray appearance absorbs too much heat. Therefore, by improving the situation through a double-layer structure, a temperature drop of $5.9^{\circ} \mathrm{C}$ was reached compared to non-coated concrete under simulated sunlight, simultaneously with a low heating rate and high cooling rate. Besides, the binding strength between the geopolymeric coating and Portland cement concrete is comparable to two commercial organic paints. It is highly probable that the utilization of $\mathrm{BOF}$ slag in geopolymeric coating is energy saving and also feasible for passive radiative cooling applications. Hence, it can greatly decrease indoor temperature and improve the comfort of people living in buildings.
\end{abstract}

Keywords: geopolymer; passive radiative cooling; basic oxygen furnace slag; inorganic coating

\section{Introduction}

The latest annual average temperature anomaly of 2018, compared with the past long-term global temperature average, was $0.8^{\circ} \mathrm{C}$ warmer [1]. If this pace of warming continues, it will reach $1.5^{\circ} \mathrm{C}$ around 2040 [2]. At the same time, the urban heat island effect (UHI) has drawn more and more attention around the world [3-6]. The solutions of this bad situation for maintaining the comfortability of people's lives have emerged [7,8]. Passive radiative cooling (PRC) is a feasible approach that terrestrial heat can be distributed throughout the atmosphere without absorption and reflection $[9,10]$. It usually derived from a material which has high emissivity across the spectrum of $8 \sim 13 \mu \mathrm{m}$ known as "sky window". Because of a large excess of heat from urban surfaces consisting of buildings, asphalt, 
bare soil, and short grasses [11], coating which has the function of PRC is applicable to buildings' exteriors [12-14].

There are lots of studies focusing on PRC coating at present. Li et al. [15] made tridymite-type aluminum phosphate at a high temperature and formed a coating by PVDF (Polyvinylidene difluoride), which reached the emissivity of 0.90 across the sky window; Zhai et al. [16] embedded a solid glass ball in 4-methylpentene to produce a scalable-manufactured thin film, which had the emissivity of 0.93 across the sky window; Zhang et al. [17] prepared a silica thin film by a hot pressing process with PET (Polyethylene terephthalate) for PRC; and Bao et al. [18] developed a multi-layer coating with rutile $\mathrm{TiO}_{2}$, nano- $\mathrm{SiO}_{2}$, and isopropanol solvent, which achieved an emissivity of 0.90 across the sky window. However, the organic binder mentioned above and used by all of the researchers is usually produced by non-renewable petroleum and its sub-products $[19,20]$. Therefore, the environmentally friendly geopolymeric coating can be carried forward due to its great developmental potential nowadays [21-23].

In this study, the geopolymeric coating used basic oxygen furnace slag (BOFs) as the bottom layer of a PRC coating, which possessed high emissivity [24] in the "sky window". It is notable that BOF slag is produced in the steelmaking process in quantities of 100-150 kg slag per ton of steel [25] in oxygen converter procedures. That is to say, this resource is prevalent and adequate. Combined with another white geopolymeric coating as a reflective layer, this double-layer structure can have a better effect on PRC [18]. In brief, this PRC geopolymeric coating, owing to a simple process and easily gained material, has great potential for economic competitiveness, environmental concerns, and wide application on building exteriors in tropical and temperate zones in the future.

\section{Experiment Process \& Material}

\subsection{Materials and Preparation}

In this study, the materials in powder form can be classified into 3 types: passive radiative cooling (PRC) powder, modifying powder, and geopolymer powder. PRC powder includes cordierite and BOFs which both have high emissivity in the "sky window" [24,26]; modifying powder includes titanium oxide and calcium carbonate, which both have a great white appearance [18,27]; and geopolymer powder includes metakaolin and calcium silicate. Calcium silicate was used for improving anti-crack characteristics. The chemical composition and $\mathrm{D}_{50}$ of the powders are listed in Table 1.

Table 1. Chemical composition and $\mathrm{D}_{50}$ of materials.

\begin{tabular}{|c|c|c|c|c|c|c|c|c|c|c|c|}
\hline Material Composition (wt.\%) & $\mathrm{SiO}_{2}$ & $\mathrm{Al}_{2} \mathrm{O}_{3}$ & $\mathrm{TiO}_{2}$ & $\mathrm{Fe}_{2} \mathrm{O}_{3}$ & $\mathrm{~K}_{2} \mathrm{O}$ & $\mathrm{CaO}$ & $\mathrm{ZnO}$ & $\mathrm{MgO}$ & Others & L.O.I & $\mathrm{D}_{50}(\mu \mathrm{m})$ \\
\hline Metakaolin & 55.2 & 39.6 & 2.4 & 0.7 & - & - & - & - & 0.1 & 1.5 & 4.7 \\
\hline $\begin{array}{l}\text { Calcium } \\
\text { silicate }\end{array}$ & 58.3 & 33.1 & - & 2.7 & 1.5 & 0.3 & - & - & 1.7 & 0.6 & 27.1 \\
\hline Cordierite & 47.4 & 31.5 & - & - & - & - & - & 11.3 & 6.1 & 2.8 & 48.9 \\
\hline $\begin{array}{l}\text { Titanium } \\
\text { oxide }\end{array}$ & 0.6 & 1.3 & 96.3 & - & - & - & 0.3 & - & 1.1 & 0.3 & 0.4 \\
\hline $\begin{array}{l}\text { Calcium } \\
\text { carbonate }\end{array}$ & 0.6 & - & - & - & - & 56.5 & - & 4.4 & - & 37.5 & 24.9 \\
\hline BOF slag & 11.5 & 4.5 & 0.5 & 21.6 & - & 39.4 & - & 6.4 & 12.1 & 3.9 & 13.6 \\
\hline
\end{tabular}

The coatings were made from the materials above. Two kinds of coating were developed in this study. One was a white cordierite coating, represented by " 510 ". The other one was a gray BOFs coating, represented by "BOF". The compositions of white 510 [28] and gray BOF coating are shown in Tables 2 and 3, respectively. The ratio of powder to solution was fixed at 1 . For better emissivity, the improved composition of the gray BOF coating is shown in Table 4 . All the ratios of liquid to powders in the coating were controlled at 0.81 . 
Table 2. Composition of the white cordierite coating.

\begin{tabular}{ccccccccc}
\hline \multirow{2}{*}{ Code } & \multicolumn{4}{c}{ Powders (wt.\%) } & \multicolumn{3}{c}{ Solution (wt.\%) } \\
\cline { 2 - 9 } & Cordierite & $\begin{array}{c}\text { Calcium } \\
\text { Carbonate }\end{array}$ & $\begin{array}{c}\text { Titanium } \\
\text { Oxide }\end{array}$ & Metakaolin & $\begin{array}{c}\text { Calcium } \\
\text { Silicate }\end{array}$ & $\begin{array}{c}\text { Alkaline } \\
\text { Solution }\end{array}$ & $\begin{array}{c}\text { Colloidal } \\
\text { Silica }\end{array}$ & Dispersant \\
\hline 510 & 30 & 20 & 20 & 20 & 10 & 40 & 40 & 1 \\
\hline
\end{tabular}

Table 3. Composition of the basic oxygen furnace (BOF) inorganic coating.

\begin{tabular}{ccccccc}
\hline & \multicolumn{3}{c}{ Powders (wt.\%) } & \multicolumn{3}{c}{ Solution (wt.\%) } \\
\cline { 2 - 7 } Code & BOFs & Metakaolin & $\begin{array}{c}\text { Calcium } \\
\text { Silicate }\end{array}$ & $\begin{array}{c}\text { Alkaline } \\
\text { Solution }\end{array}$ & $\begin{array}{c}\text { Colloidal } \\
\text { Silica }\end{array}$ & Dispersant \\
\hline BOF & 55 & 35 & 10 & 40 & 40 & 1 \\
\hline
\end{tabular}

Table 4. Composition of improved BOF inorganic coating.

\begin{tabular}{ccccccc}
\hline & \multicolumn{3}{c}{ Powders (wt.\%) } & \multicolumn{3}{c}{ Solution (wt.\%) } \\
\cline { 2 - 7 } Code & BOFs & Metakaolin & $\begin{array}{l}\text { Calcium } \\
\text { Silicate }\end{array}$ & $\begin{array}{c}\text { Alkaline } \\
\text { Solution }\end{array}$ & $\begin{array}{c}\text { Colloidal } \\
\text { Silica }\end{array}$ & Dispersant \\
\hline BOF-10\% & 10 & 80 & & & & \\
BOF-30\% & 30 & 60 & 10 & 40 & 40 & 1 \\
BOF & 55 & 35 & & & & \\
BOF-70\% & 70 & 20 & & & \\
\hline
\end{tabular}

The experiment procedure is depicted in Figure 1. First of all, PRC powder was mixed with the geopolymer powder for $1 \mathrm{~min}$. This became the original coating powder, which was called PRC geopolymeric coating powder. This mixed powder was analyzed by an emissivity test, UV-VIS, and FT-IR) spectroscopy. The PRC geopolymeric coating powder was added to an alkaline solution, which was prepared through dissolving $\mathrm{KOH}$ (Potassium hydroxide) pellets in water with a molar concentration of $6 \mathrm{M}$, cooled to room temperature. Potassium silicate and sodium aluminate were used with molar ratios of $\mathrm{SiO}_{2} / \mathrm{K}_{2} \mathrm{O}=1.28$ and $\mathrm{SiO}_{2} / \mathrm{Al}_{2} \mathrm{O}_{3}=50$. After 5 min of mixing, the metakaolin and calcium silicate powder reacted with the alkaline solution as a binder. Colloidal silica was also used to increase the adhesion between the coating and the substrate [29]. Next, the slurry was painted onto the substrate twice, but in a different direction to make the coating smoother; then it dried at room temperature for 1 day. After the second layer coating was painted using the same process, a wooden box simulation test, conductivity test, and an adhesion test were performed. Notably, in order to compare the PRC effect between the geopolymeric coating and commercial coating, two brands of commercial organic coating were used and tested in the same method in this study.

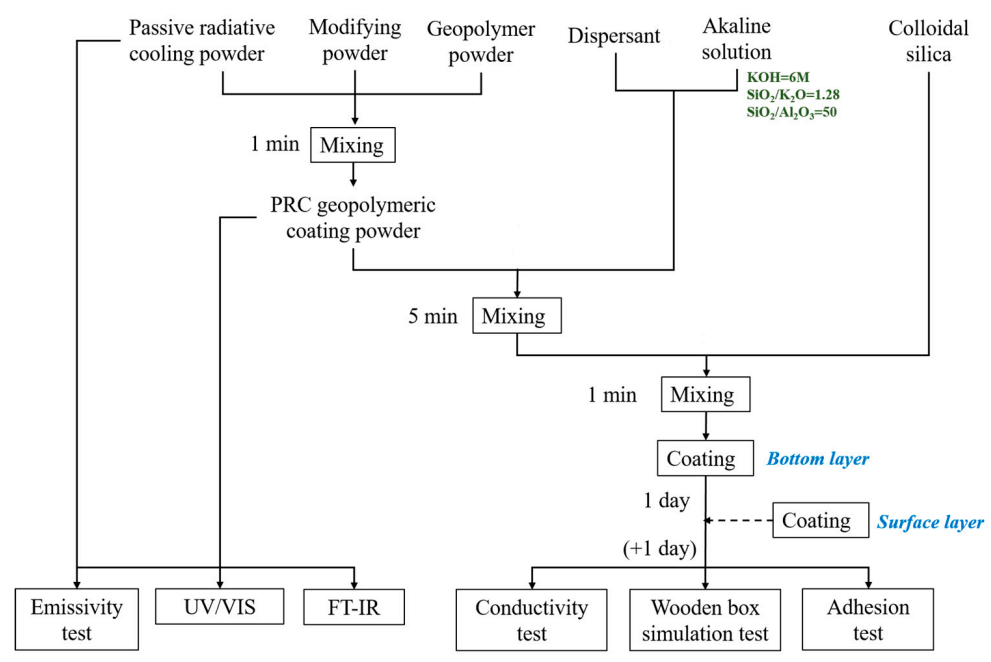

Figure 1. Overall experiment procedure. 


\subsection{Characterization}

The composition of the PRC geopolymeric coating powder needed to be characterized within the mid-infrared spectral emissivity $(4-16 \mu \mathrm{m})$ at a specific temperature by a Fourier transform infrared (FT-IR) spectrometer (Vertex 70, Bruker, Karlsruhe, Germany), equipped with infrared heaters, via the spectral emissivity measurement method [30]. The calibrated blackbody possesses an emissivity of 0.99 . The UV-VIS diffuse reflectance spectrum of the powder was obtained on a UV spectrophotometer (UV-2550, Shimadzu, Torrance, CA, USA) equipped with an integrating sphere, using BaSO4 as a reference. The vibration absorption $(2.5-20 \mu \mathrm{m})$ of the original coating was tested by the FT-IR spectrometer equipped with ATR (Platinum ATR, Bruker, Karlsruhe, Germany). The coating painted on the concrete substrate was characterized using three methods: a wooden box simulation test was recorded by thermocouples with a thermometer (DTM319, Tecpel, New Taipei City, Taiwan); the conductivity was tested by a quick thermal conductivity meter (QTM-500, KEM, Tokyo, Japan); and the adhesion was measured by pull-off adhesion testers (PosiTest ${ }^{\circledR}$ AT, DeFelsko, Ogdensburg, NY, USA).

\section{Result \& Discussion}

\subsection{Material Selection}

To find a great PRC material for coating, firstly testing its emissivity by FT-IR is an efficient method. According to Table 5, the emissivity of cordierite powder can reach 0.93 at $8 \sim 13 \mu \mathrm{m}$, although when it is made into 510 coating powder its emissivity can still reach 0.92 ; BOFs powder possesses an emissivity value of 0.95 at $8 \sim 13 \mu \mathrm{m}$ and mixed into BOF coating powder even has an emissivity value of 0.92 . Besides that, Figure 2 shows the additive effect on different kinds of material being mixed together, with the emissivity curve of cordierite powder (the highest addition) similar to 510 coating powder. The same trend in BOF coating powder can be observed in Figure 3. Some emissivity values greater than 1 could be due to the difference between the blackbody in the FT-IR and the standard blackbody.

Table 5. Mean emissivity of 510 and BOF powders and their composition.

\begin{tabular}{cccccccccc}
\hline $\begin{array}{c}\text { Mean } \\
\text { Wavelength }\end{array}$ & 510 Coating & $\begin{array}{c}\text { Calcium } \\
\text { Carbonate }\end{array}$ & $\begin{array}{c}\text { Calcium } \\
\text { Silicate }\end{array}$ & Cordierite & Metakaolin & $\begin{array}{c}\text { Titanium } \\
\text { Oxide }\end{array}$ & $\begin{array}{c}\text { BOF } \\
\text { Coating }\end{array}$ & BOFs \\
\hline $8 \sim 13 \mu \mathrm{m}$ & 0.92 & 0.81 & 0.88 & 0.93 & 0.91 & 0.80 & 0.95 & 0.92 \\
$2.5 \sim 15.4 \mu \mathrm{m}$ & 0.87 & 0.65 & 0.63 & 0.64 & 0.59 & 0.51 & 0.75 & 0.82 \\
\hline
\end{tabular}

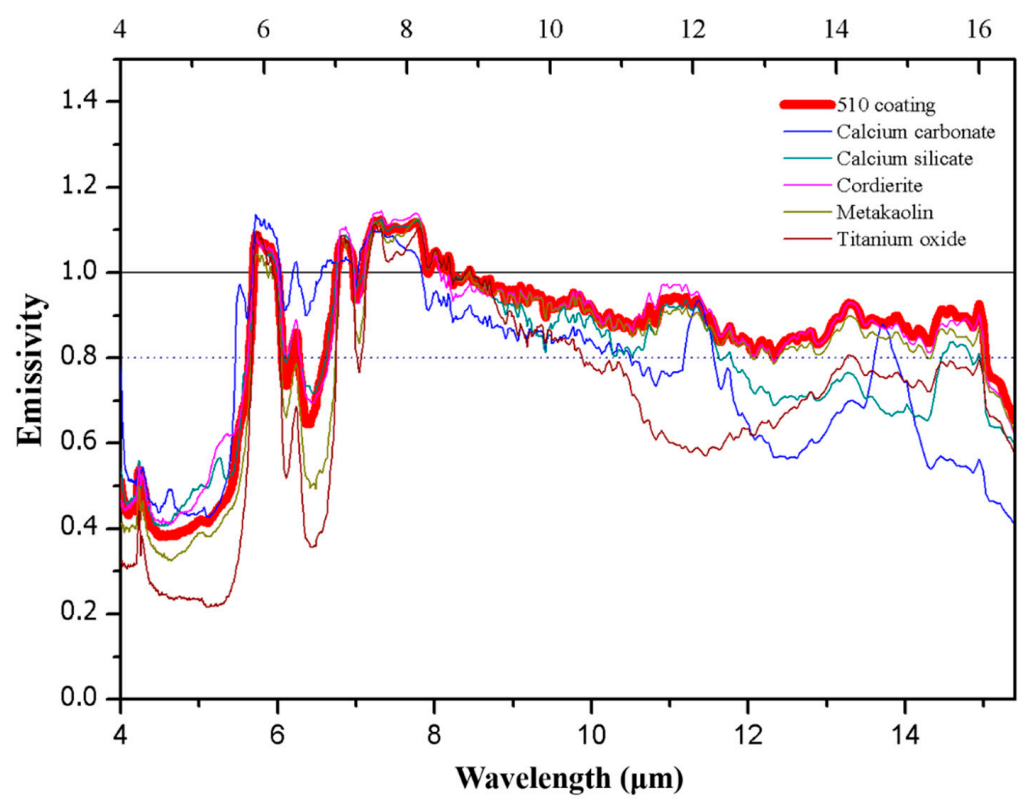

Figure 2. The emissivity of 510 coating powder and its composition. 


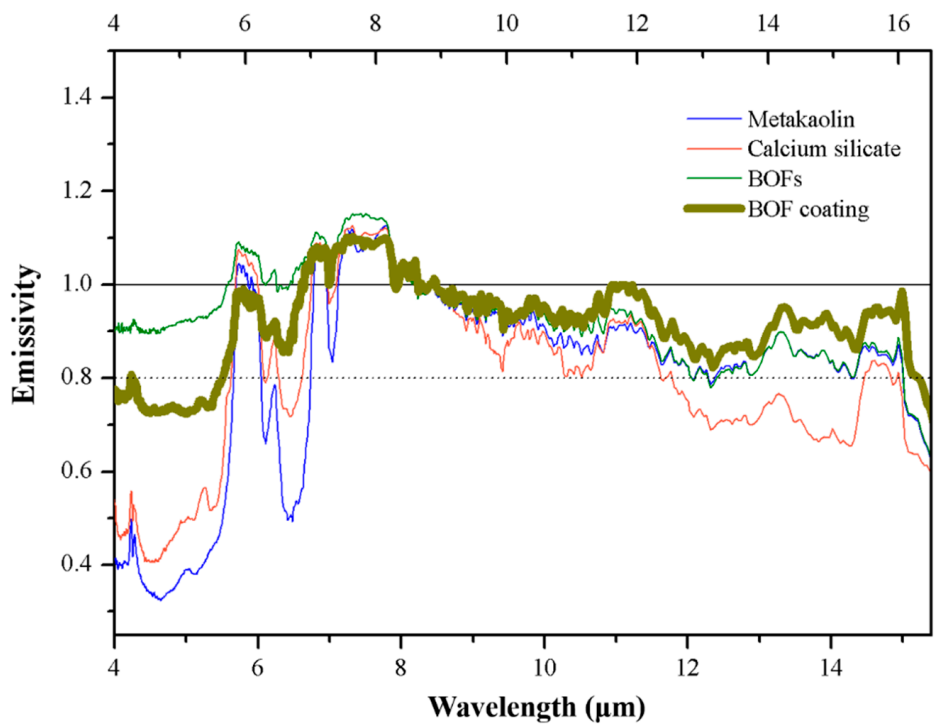

Figure 3. The emissivity of BOF coating powder and its composition.

\subsection{Optical Property}

To achieve a great PRC effect, a double-layer coating structure [18], which was comprised of a highly solar-reflective top layer and a highly emissive underlying layer, was used in this study. The 510 coatings were utilized as a reflection layer, but with little effect on PRC, and BOF was used as a stronger emission layer. Figure 4 shows the spectrum reflectivity of 510 coating powder. As shown in the spectral reflectivity curves with solar irradiance (AM1.5), 510 coating powder reached $80 \%$ reflectivity in the VIS region, where there was also the strongest solar irradiance. A coating with higher reflectivity used on a building exterior can increase temperature reduction [31]. On the other hand, according to the basic law of light [32], $\mathrm{A}+\mathrm{T}+\mathrm{R}=1$, where $\mathrm{A}, \mathrm{T}$, and $\mathrm{R}$ are absorptivity, transmissivity, and reflectivity. For the opaque 510 coatings, $\mathrm{T}$ is 0 , therefore $\mathrm{A}=1-\mathrm{R}$. In the FIR region, calculated by the above method, the 510 coatings can reach around $15 \%$ reflectivity in the "sky window" region, as shown in Figure 4. Kirchhoff's law of thermal radiation states that [33] under thermal equilibrium, A and emissivity are equal for every wavelength. Therefore, high emissivity corresponds to low reflectivity. This means 510 coatings possessing low reflectivity are helpful to PRC. However, more than that, putting a BOF coating under a 510 coating may improve the overall emissivity.

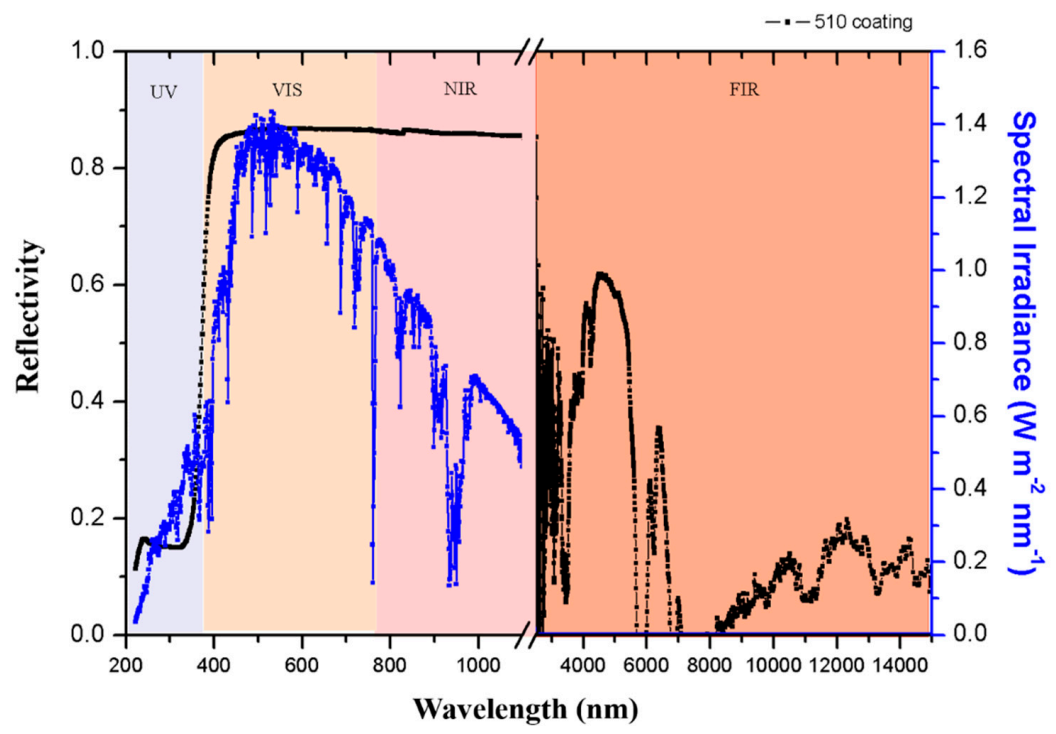

Figure 4. Reflectivity at UV-VIS-NIR-FIR wavelengths. 
In order to improve overall emissivity, using a BOF coating as the underlying layer is feasible. As illustrated in Figure 5, higher emissivity followed an increase in the amount of BOFs until around $55-70 \%$. This means that the addition of 55\% BOFs is close to the upper limit. Table 6 summarizes the mean emissivity values. Compared to the non-coated concrete, an addition of $55 \%$ of BOFs already achieved great emissivity.

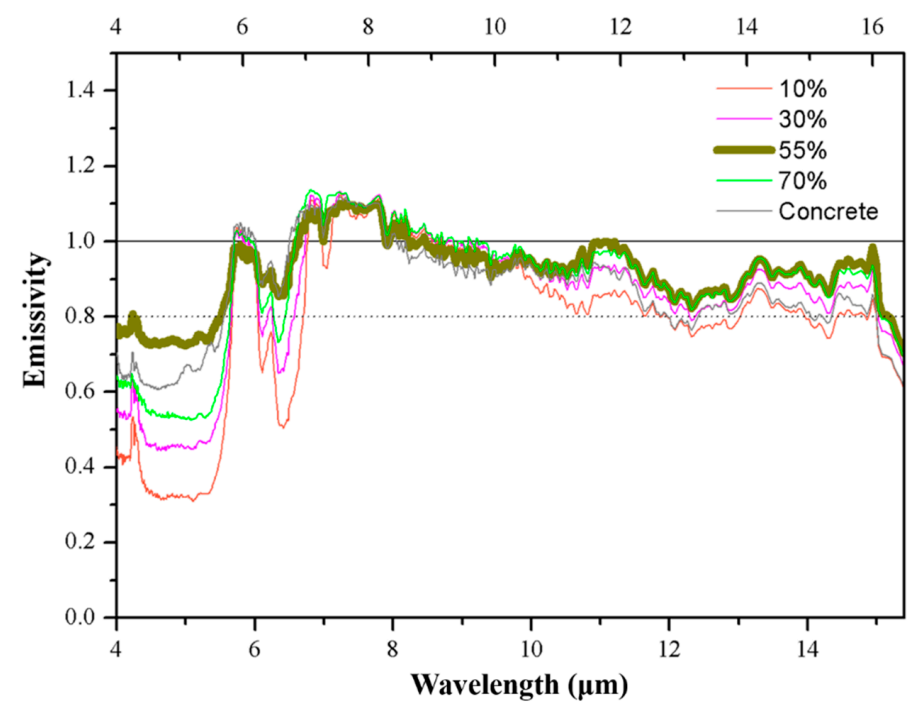

Figure 5. The emissivity of different amounts of basic oxygen furnace slag (BOFs) added to the BOF coating.

Table 6. Mean emissivity of different amounts of BOFs added to the BOF coating.

\begin{tabular}{cccccc}
\hline \multicolumn{1}{c}{ BOFs Addition } & $\mathbf{1 0 \%}$ & $\mathbf{3 0} \%$ & $\mathbf{5 5 \%}$ & $\mathbf{7 0} \%$ & Concrete \\
\cline { 1 - 4 } Mean Wavelength & & & & & \\
\hline $8 \sim 13 \mu \mathrm{m}$ & 0.93 & 0.96 & 0.97 & 0.98 & 0.91 \\
$2.5 \sim 15.4 \mu \mathrm{m}$ & 0.73 & 0.75 & 0.80 & 0.78 & 0.71 \\
\hline
\end{tabular}

\subsection{Wooden Box Simulation Temperature Test}

In the double-layer coating structure, 510 coating was the top layer and BOF coating was the underlying layer. Meanwhile, the one-layer coatings (510 or BOF) were also tested to compare with the double-layer coating. All coatings were painted by brush on Portland cement concrete. Every coating with a thickness of 180 250 $\mu \mathrm{m}$ possessed the optimal properties and was also practical for use. After the prior work was finished, the samples were tested by the measurement apparatus.

The details of the measurement apparatus are shown in Figure 6. This apparatus was designed to simulate the temperature change of a building — especially a thick-walled and airtight one-with geopolymeric coatings during a day. In order to study the thermal insulation properties for coatings, every sample used a solar lamp irradiating at a $20 \mathrm{~cm}$ distance at $45^{\circ}$ from the center of the concrete [34]. At the same time, the sun lamp was controlled by a timer, and the thermocouples recorded all temperature changing on the surface and bottom of concrete. On the other hand, the internal temperatures changing in the wooden box were also recorded. To avoid weather disruption, this wooden box simulation temperature test was carried out in the basement of the Mineral and Material Building at Taipei Tech University, Taiwan.

To analyze the PRC effect using a temperature test, the raw data from the concrete's surface and the bottom of the concrete and the internal temperature should be minus the ambient temperature, to reduce the impact of the weather. There are four related figures that need to be explained: for instance, Figure $7 \mathrm{a}$ is the raw data for 12 p.m. and 12 a.m. in the test. Figure $7 \mathrm{~b}$ shows the temperature difference during 3 periods of time: 300 min was the time at which all the samples struck a heat balance; 720 min 
was the time at which the light turned off instantly, meaning the temperature was highest; 1440 min was the time at which it can be speculated that the PRC effect depended on the heat absorbed and released at the same time. The above times were used to calculate the temperature difference. For example, " $\mathrm{T}_{300}-\mathrm{T}_{0}$ " was the temperature value after $300 \mathrm{~min}$ light had been absorbed, minus the temperature value at the beginning and so on for the others. Each gray bar represented the temperature difference compared with non-coated concrete. A lower value meant a better effect on PRC. The heating rate and cooling rate by MATLAB approximate calculation in the first-order differential are shown in Figure $7 \mathrm{c}, \mathrm{d}$. A lower temperature variation in the heating rate meant a better PRC effect; a higher variation in the cooling rate achieved a better effect. Four kinds of figures were used for analyzing the temperature of the concrete's surface and the bottom of the concrete, and the internal temperature (house) of the wooden box, with comparisons among 510 coatings, BOF coating, and double-layer coatings $(510+\mathrm{BOF})$.

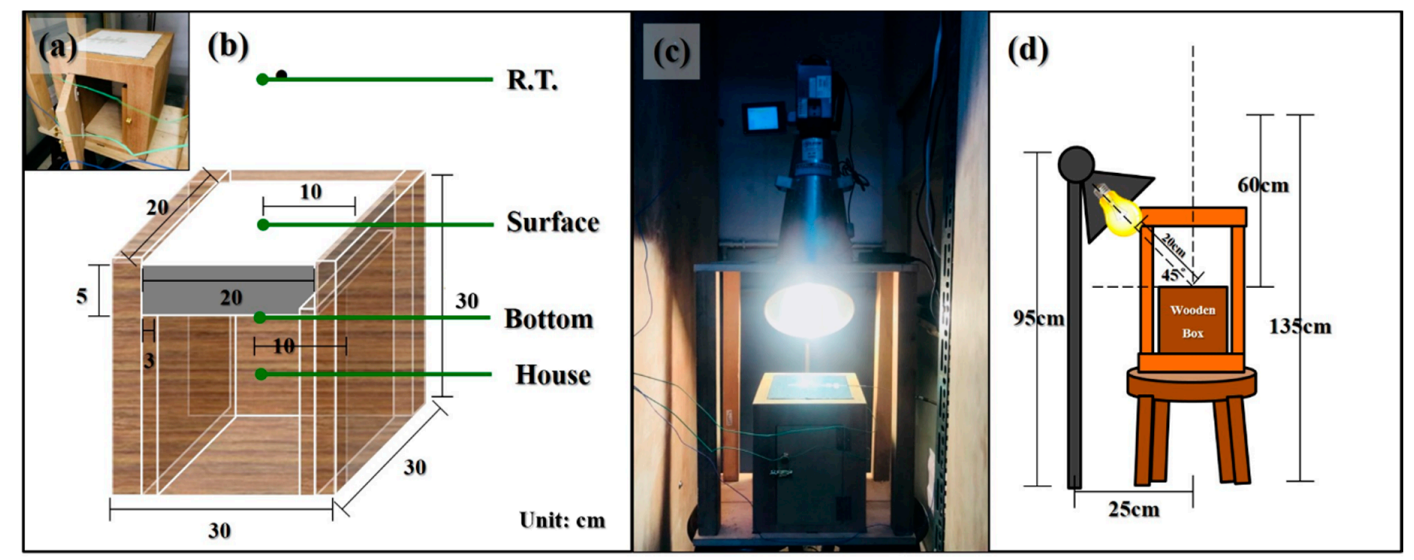

Figure 6. (a) Photo of the wooden box. (b) Perspective illustration of the wooden box. (c) Photo of the apparatus working in progress. (d) Perspective illustration of the apparatus.

(a)

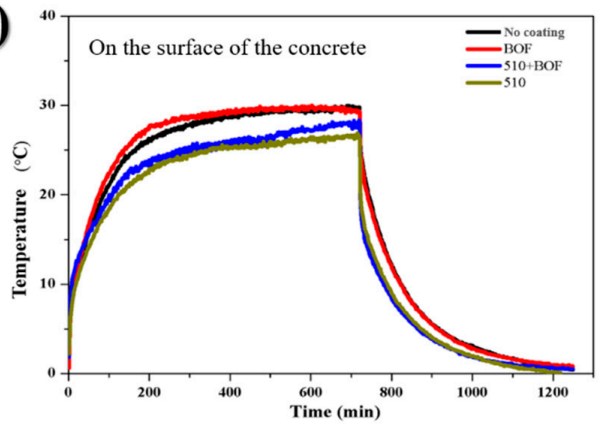

(b)

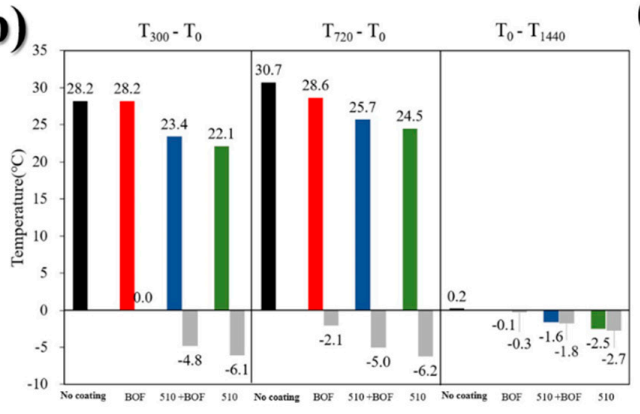

(c)

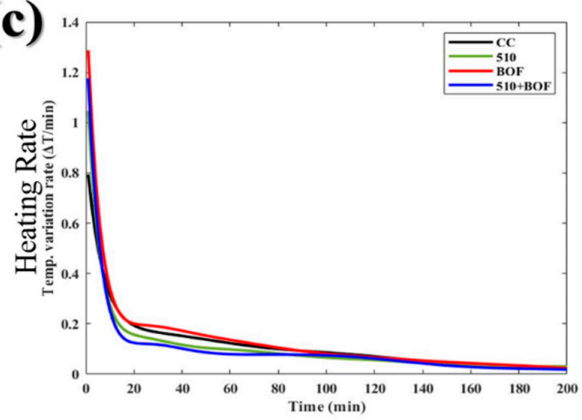

(d)

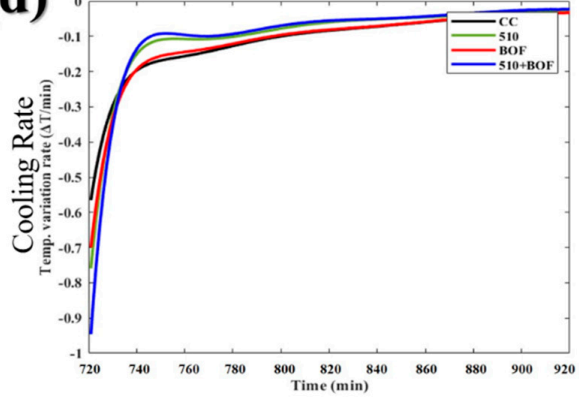

Figure 7. The influence of BOF, 510, and 510+BOF coatings on the concrete's surface: (a) the temperature variation in daytime and nighttime; (b) temperature difference at 300, 720, and $1440 \mathrm{~min}$; (c) heating rate; (d) cooling rate. 


\subsubsection{One-Layer and Double-Layer Coating}

In Figure $7 \mathrm{a}, \mathrm{b}$ it can clearly be seen that on the concrete's surface 510 and $510+\mathrm{BOF}$ were better than the non-coating and BOF. The result, seen in Table 7, that BOF possessed a high temperature is not surprising due to not only its gray appearance but also because the high content of $\mathrm{Fe}_{2} \mathrm{O}_{3}$ would lead to high conductivity. It was also found that the BOF and 510+BOF coatings has similar conductivity. Therefore, it is inferred that the top layer, which has a vital effect on reflection, is the main cause of the temperature. Meanwhile, Figure $7 \mathrm{c}, \mathrm{d}$ show that painting a 510 coating improved the heating rate and cooling rate. Meanwhile, the double-layer coating had a similar trend but narrowly beat the 510 coating. As a consequence, a PRC effect on concrete can be expected.

Table 7. Conductivity of one-layer and double-layer coatings on Portland cement concrete.

\begin{tabular}{ccccc}
\hline Code & Non-Coating & BOF & $\mathbf{5 1 0}$ & $\mathbf{5 1 0 + B O F}$ \\
\hline $\begin{array}{c}\text { Conductivity } \\
\left(\mathrm{W} / \mathrm{m}^{2} \mathrm{k}\right)\end{array}$ & 1.86 & 2.27 & 2.00 & 2.26 \\
\hline
\end{tabular}

As shown in Figure 8a, on the bottom of the concrete, the double-layer coating decreased the temperature by $6.2^{\circ} \mathrm{C}$ in $720 \mathrm{~min}$. Simultaneously, with the BOF coating the temperature decreased about $1{ }^{\circ} \mathrm{C}$ by PRC, as it did with 510 coating and the double-layer coating. Besides, the heating rate of the double-layer coating was the lowest and the cooling rate was the highest, as shown in Figure 8c,d.

(a)

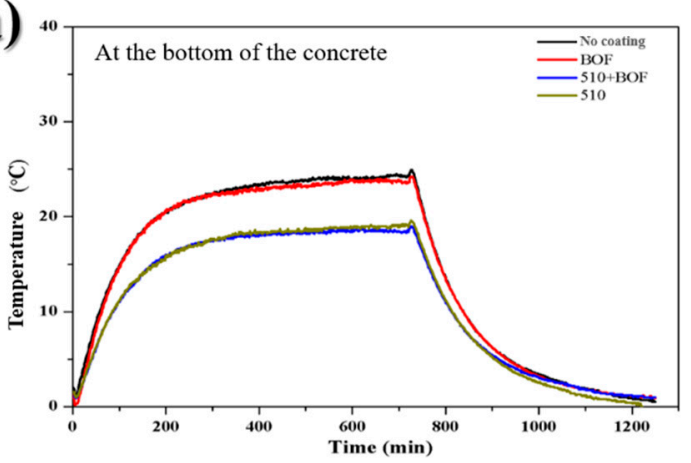

(b)

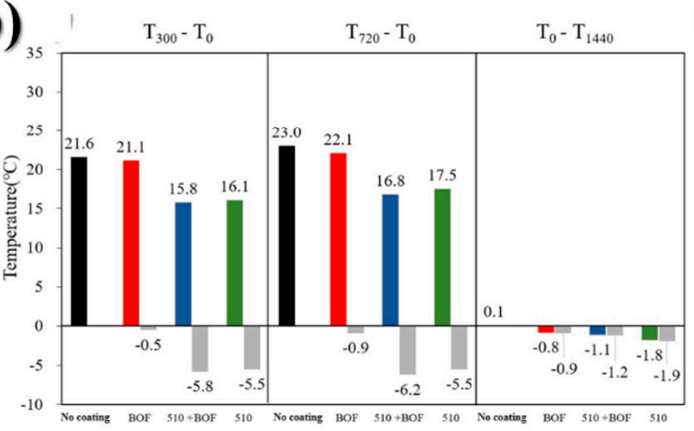

(c)

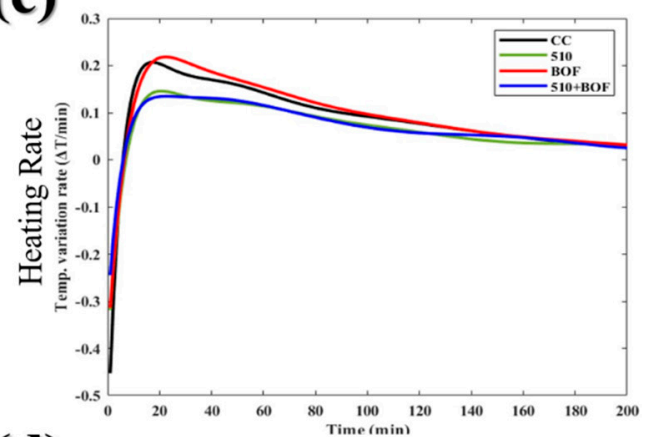

(d)

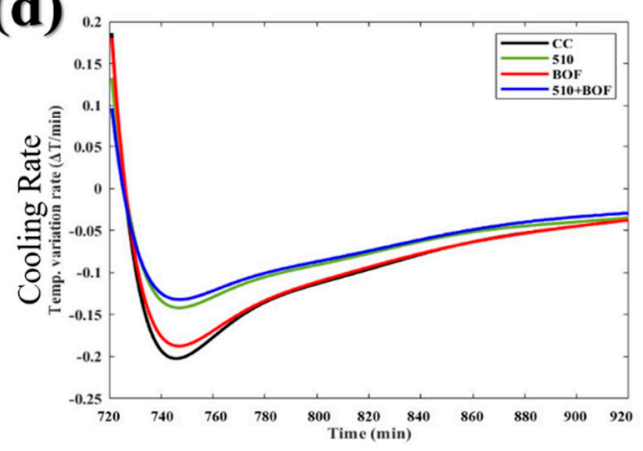

Figure 8. The influence of BOF, 510, and 510+BOF coatings on the bottom of the concrete: (a) the temperature variation in daytime and nighttime; (b) temperature difference at 300, 720, and $1440 \mathrm{~min}$;

(c) heating rate; (d) cooling rate.

Exploring the internal temperature of the wooden box, one-layer and double-layer coatings showed a similar effect on the temperature of not more than $1{ }^{\circ} \mathrm{C}$, as shown in Figure $9 \mathrm{~b}$. Compared with the temperature variation rate in Figure $9 \mathrm{c}, \mathrm{d}$, the double-layer coating had the fastest cooling rate. Based on the above-mentioned results, the double-layer coating, which had a better PRC effect, cooled down the concrete's surface by $5{ }^{\circ} \mathrm{C}$ and the bottom by about $6.2^{\circ} \mathrm{C}$ in $720 \mathrm{~min}$. Besides, it possessed a low 
heating rate and a high cooling rate. Therefore, choosing double-layer comparisons to commercial paint is the follow-up test.
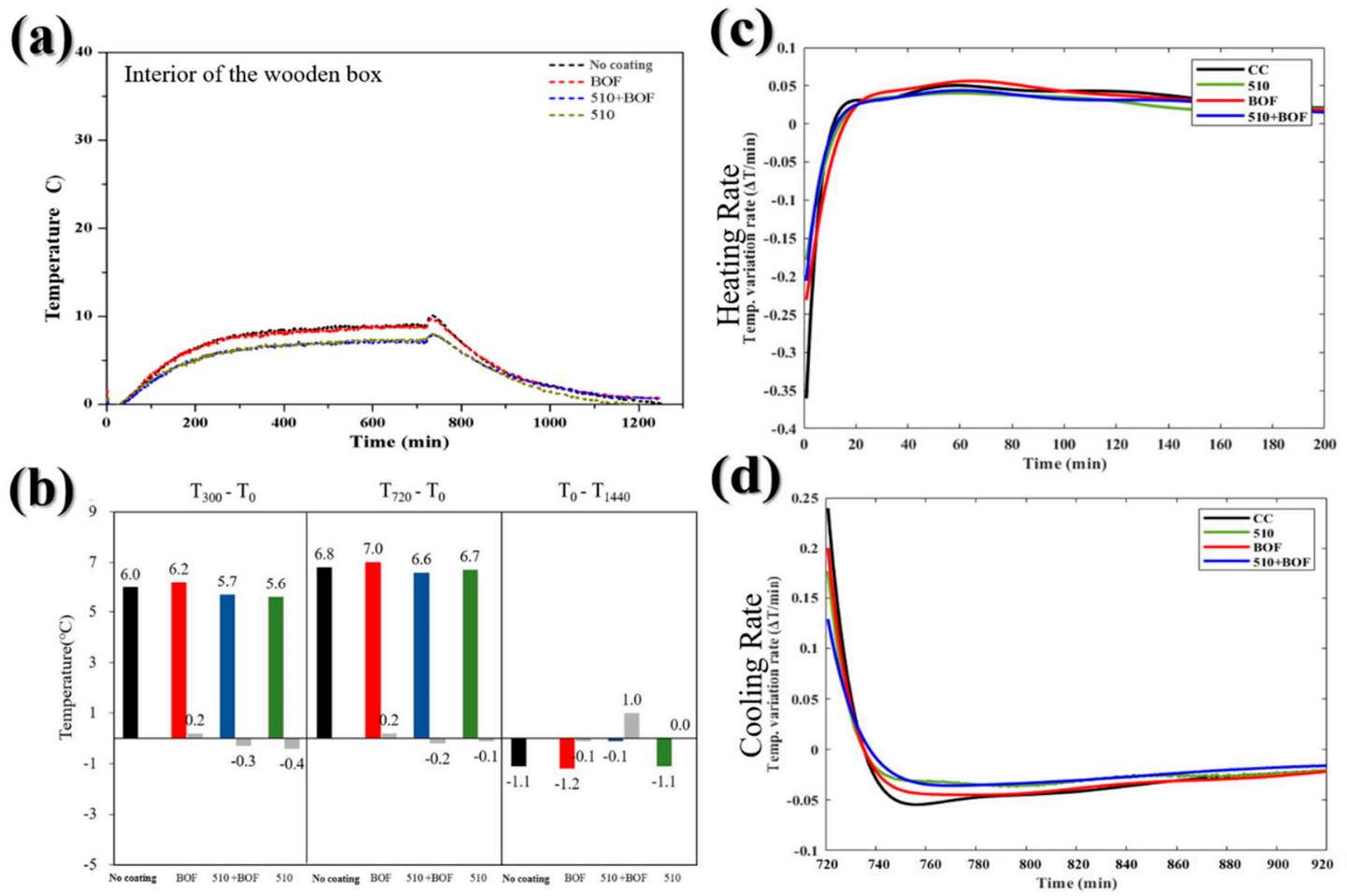

Figure 9. The influence of BOF, 510, and 510+BOF coatings in internal wooden box: (a) the temperature variation in daytime and nighttime; (b) the temperature difference at 300, 720, and $1440 \mathrm{~min}$; (c) heating rate; (d) cooling rate.

For overall analysis, 510 coating has a high reflectivity, with most of the heat being taken away by reflection, and thus the surface and bottom temperatures were lower. On the other hand, BOF coating has a high thermal conductivity; it can quickly absorb thermal energy. Although it has a high emissivity, it still caused the surface and bottom temperatures to remain high. For the 510-BOF coating, because of the white highly reflective surface layer, most of the heat could be reflected out. Only part of the heat transferred from the first layer into the second, BOF layer. A small amount of heat was absorbed by the BOF layer and resulted in PRC at $8 \sim 13 \mu \mathrm{m}$, thus reducing the temperature. Therefore, 510-BOF coating had the most thermal insulating effect.

\subsubsection{Double-Layer Coating and Commercial Paints}

Two kinds of commercial high-performance insulating exterior building paint, coated on the same substrate, were chosen as the comparisons, having similar thicknesses and the same colors of white. One commercial paint (CP1) (YungChi paint and varnish MFG. CO., LTD, Kaohsiung, Taiwan) was composed of water-based acrylic resin, reflective pigment, additives and water. The other (CP2) (Akzonobe CO., LTD, Taoyuan, Taiwan) was composed of acrylic resin, titanium dioxide, water-repellent fiber, mineral filler, and water. This section is also classified into 3 parts-concrete's surface, concrete bottom, and box internal-and they are discussed one by one.

As shown in Figure 10a,b, the double-layer coating's temperature on the concrete's surface was better than $\mathrm{CP}(1)$ but worse than $\mathrm{CP}(2)$. All coating had similar heating rate and cooling rate, as shown in Figure 10c,d. The difference in temperature of the same white-in-appearance commercial paint was due to the conductivity, shown in Table 8. 
(a)

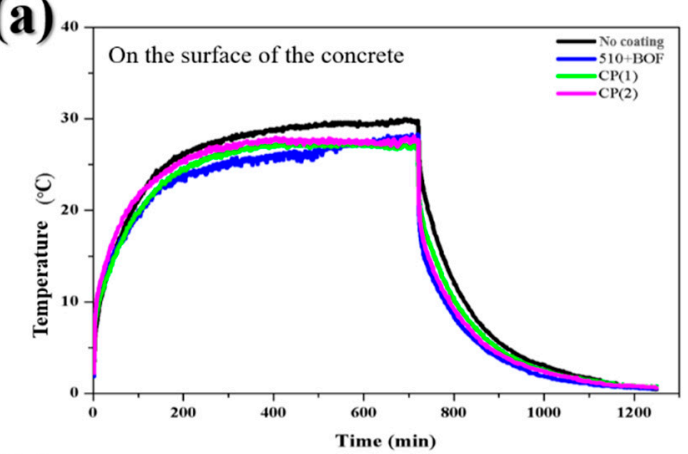

(b)

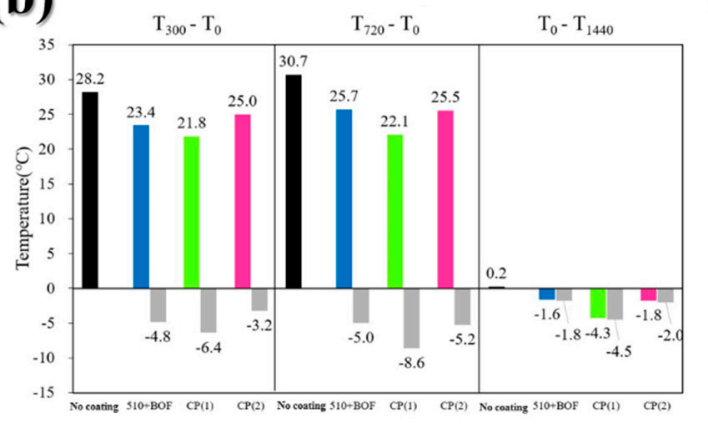

(c)

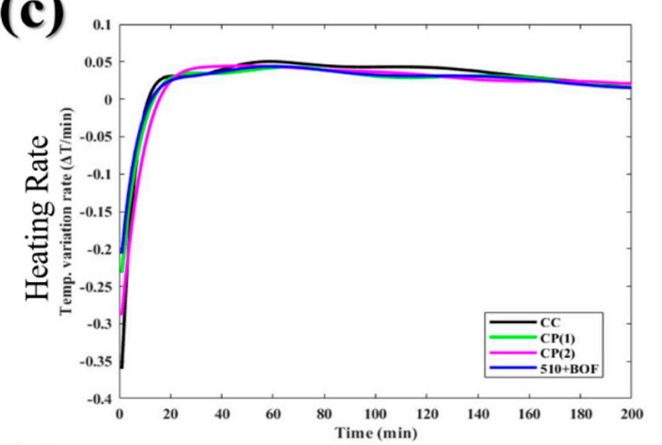

(d)

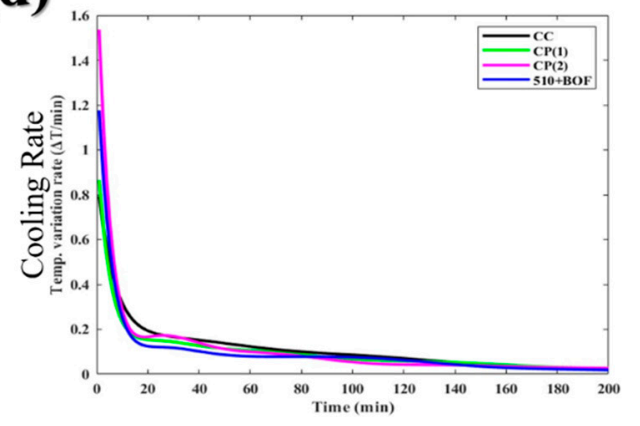

Figure 10. The influence of double-layer coating and commercial paint on the concrete's surface: (a) the temperature variation in daytime and nighttime; (b) the temperature difference at 300, 720, and $1440 \mathrm{~min}$; (c) heating rate; $(\mathbf{d})$ cooling rate.

Table 8. Conductivity of 510+BOF coatings compared with two different commercial coating on Portland cement concrete.

\begin{tabular}{ccccc}
\hline Code & Non-Coating & 510+BOF & CP(1) & CP(2) \\
\hline $\begin{array}{c}\text { Conductivity } \\
\left(\mathrm{W} / \mathrm{m}^{2} \mathrm{k}\right)\end{array}$ & 1.86 & 2.26 & 2.00 & 2.16 \\
\hline
\end{tabular}

It looks like the double-layer coating does not compare well enough with commercial paint. However, on the bottom of the concrete, the same trend-that the double-layer coating was better than $\mathrm{CP}(1)$ and $\mathrm{CP}(2)$ - can be observed in Figure 11a,b. The heating rate of the 510 coating was the lowest and the cooling rate was the highest, as shown in Figure 11c,d. Besides, the double-layer coating effectively reduced the temperature by about $6.2{ }^{\circ} \mathrm{C}$ on the bottom of the concrete. With the same white appearance of three kinds of coating, different conductivity did not influence the bottom of the concrete bottom. The same situation was also found in the previous section.

On the internal temperature of the wooden box, the double-layer coating and two kinds of commercial paint showed a similar effect, as shown in Figure 12a. Compared with the non-coated concrete in Figure 12b, others coating shown a similar effect on temperature less than $1{ }^{\circ} \mathrm{C}$. There was no clear difference with the internal temperature being the same in both the one-layer and double-layer series. This leads to speculation about the abilities of the heat dispersion by emissivity not being strong enough. In other words, the heat can penetrate the concrete into the internal space. A similar heating rate and cooling rate were demonstrated in Figure 12c, d, but the double-layer coating was still the best. Overall, the double-layer coating cooled down the concrete's surface $5^{\circ} \mathrm{C}$ and the bottom of the concrete by about $6.2^{\circ} \mathrm{C}$, with a great PRC effect on the heat dissipating. 
(a)

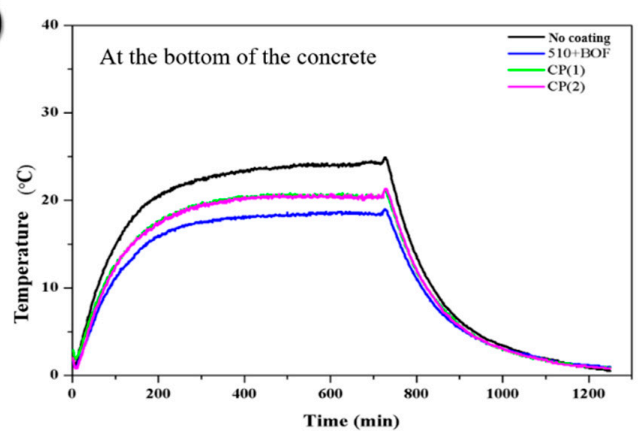

(b)

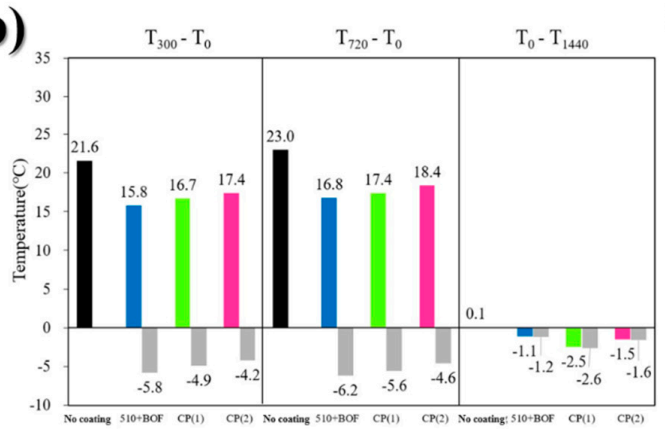

(c)

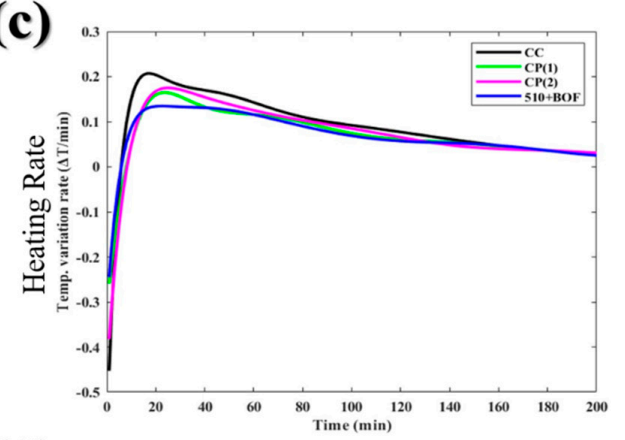

(d)

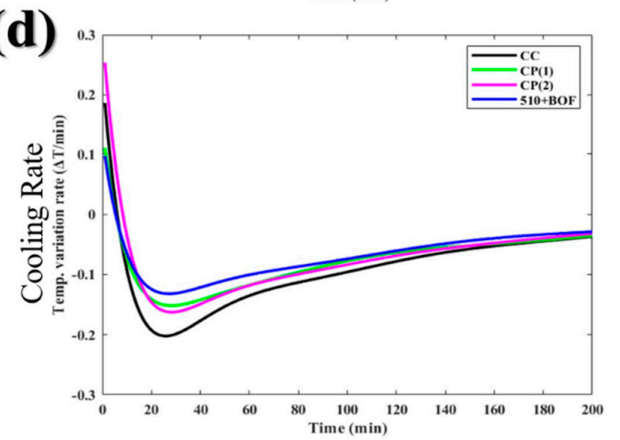

Figure 11. The influence of the double-layer coating and commercial paint on the bottom of the concrete: (a) the temperature variation in daytime and nighttime; (b) the temperature difference at 300, 720, and $1440 \mathrm{~min}$; (c) heating rate; $(\mathbf{d})$ cooling rate.

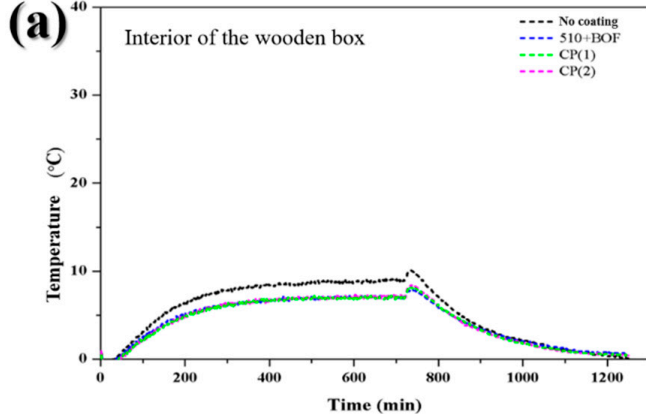

(b)

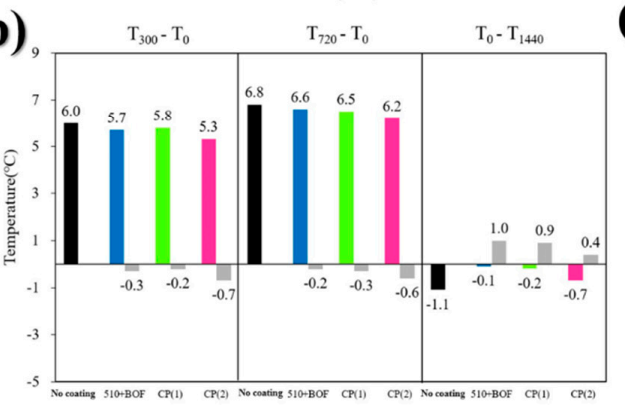

(c)

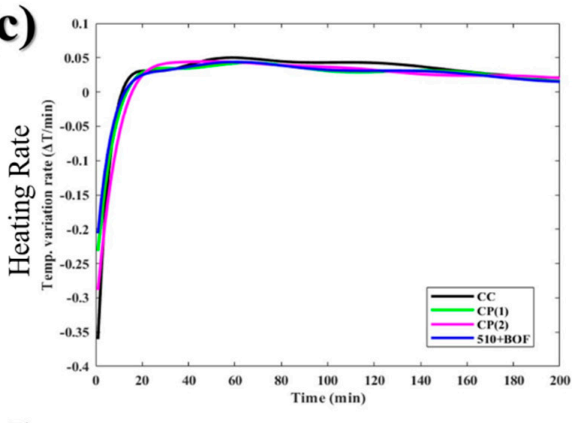

(d)

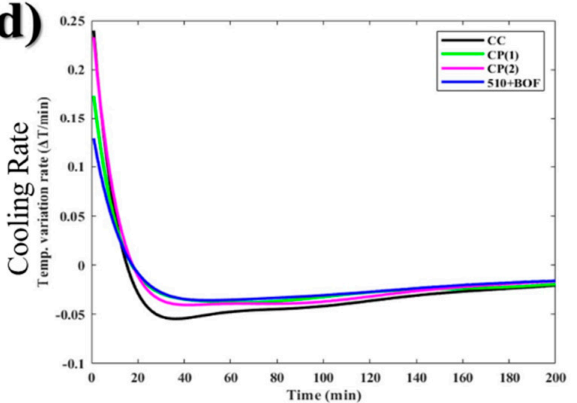

Figure 12. The influence of the double-layer coating and commercial paint in internal wooden box: (a) the temperature variation in daytime and nighttime; (b) the temperature difference at 300, 720, and $1440 \mathrm{~min}$. (c) heating rate; (d) cooling rate.

\subsection{The Adhesion of Geopolymeric Coating}

With the knowledge that the double-layer coating possesses a great PRC effect, its basic physical properties are also important. Adhesion is a primary characteristic of coatings. Consequently, compared with two kinds of commercial paintings, all geopolymeric coatings including a double-layer coating were tested. The common substrates: steel plate, 304 stainless steel plate, and Portland cement mortar 
plate were used in the test. The proposal of adding colloidal silica to the geopolymeric coating was to improve the adhesion between it and the steel [29]. However, all geopolymeric coatings did not reach a high binding power and when made into a double-layer structure they got worse, as shown in in Figure 13. In contrast, the two commercial paints showed better performance, especially on a 304 stainless steel plate. In terms of the Portland cement mortar plate, all geopolymeric coatings were not at a disadvantage. According to the results of the FT-IR for the BOF coating and the 510 coating, as shown in Figure 14, the higher binding power attributed to the $\mathrm{Si}^{4+}$ and $\mathrm{Al}^{3+}$ around a wavenumber of 1030 (Si-O-Si) and $875 \mathrm{~cm}^{-1}$ (Si-O-Al) in geopolymer material [35,36]. This bonding could react with $\mathrm{Ca}(\mathrm{OH})_{2}$ on the concrete's surface and turn into calcium silicate hydrate, resulting in a dense interface which leaded to high strength. Similar results were also reported by Pareek et al. [37].

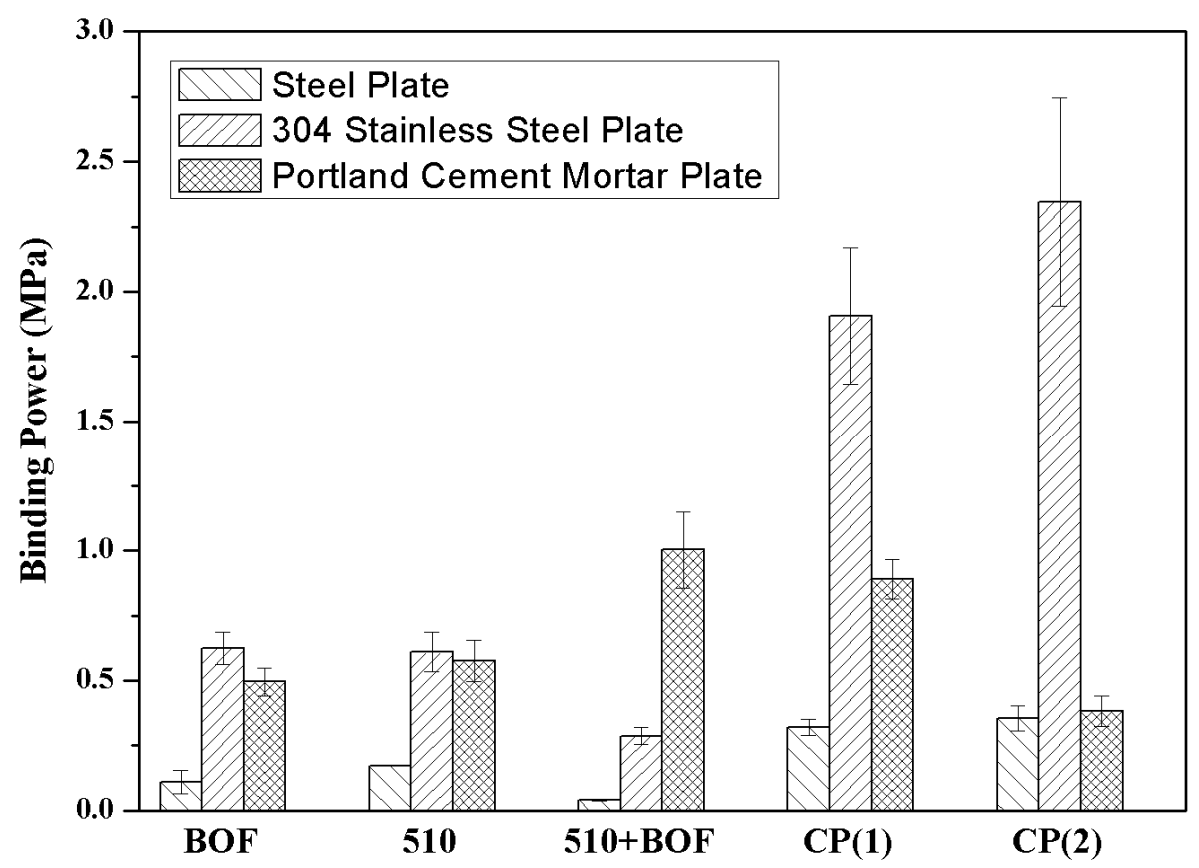

Figure 13. The adhesion of geopolymeric coatings and commercial paintings on different substrates.

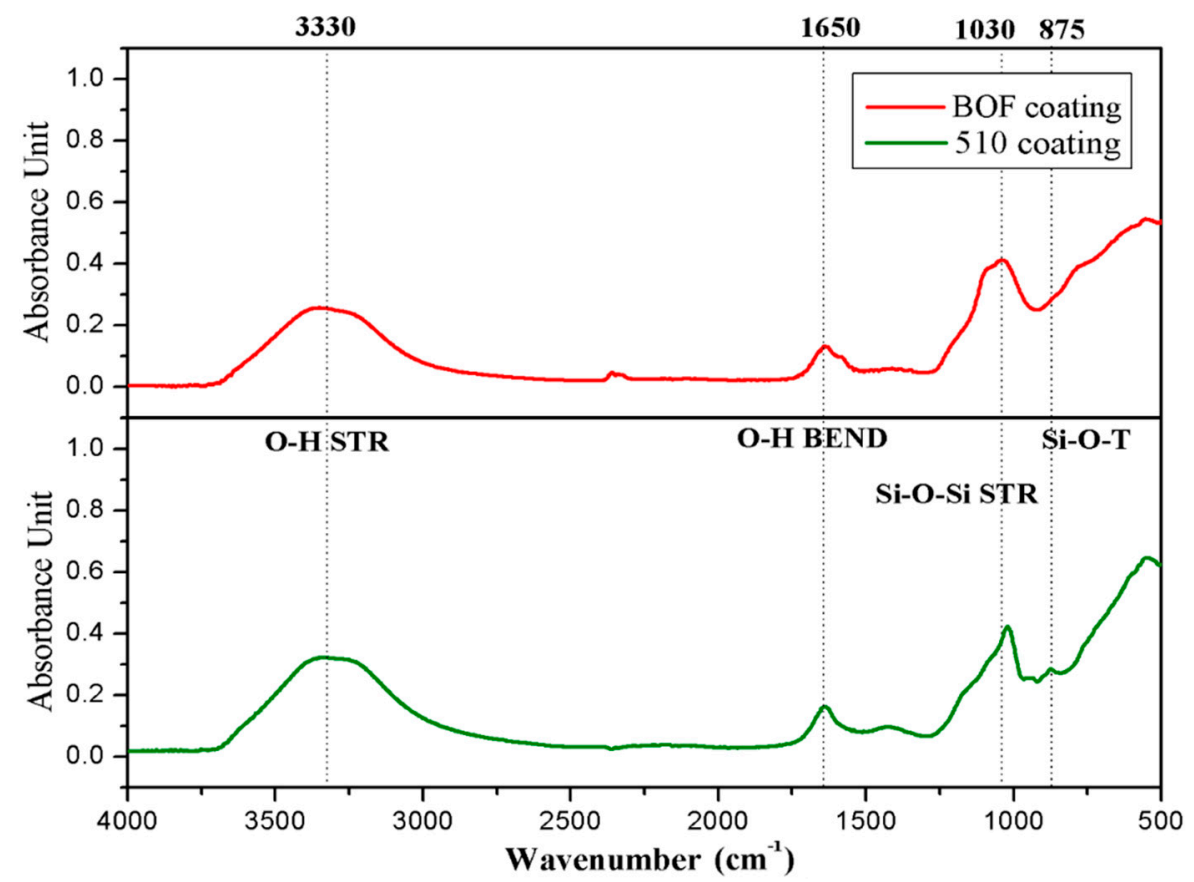

Figure 14. The FT-IR spectra of geopolymeric coating. 


\section{Conclusions}

The utilization of BOFs in geopolymeric coatings for achieving passive radiative cooling is feasible. The results are as follows:

1. The gray BOF coating with the addition of $55 \%$ BOFs possessed a high emissivity of 0.95 across the sky window. To improve the low-reflectivity gray appearance, using a 510 coating as a top layer in a double-layer structure, for the purpose of increasing the reflection, had a great effect on PRC.

2. In the wooden box simulation temperature test, the temperature of the double-layer coating dropped $5{ }^{\circ} \mathrm{C}$ lower than the ambient temperature on the concrete's surface; about $6.2{ }^{\circ} \mathrm{C}$ on the bottom of the concrete; and had a low heating rate and a high cooling rate. Besides, compared to two commercial paints, this double-layer geopolymeric coating was better.

3. The adhesion between the geopolymeric coating and Portland cement concrete was comparable to two commercial organic paints, because it can react with $\mathrm{Ca}(\mathrm{OH})_{2}$ on the concrete's surface and increase in calcium silicate hydrate, resulting in a dense interface. However, there is still room for improvement in its performance on metal substrates.

As the BOFs-based geopolymer coating is a totally inorganic coating, the results of the research have exhibited the possibility for a sustainable coating, which could further improve quality of life and also reach the concept of a circular economy.

Author Contributions: Conceptualization, T.-W.C.; methodology, T.-W.C. and C.-H.H.; investigation, C.H.W., W.-H.L. and T.-W.C.; date curation, W.-H.L.; writing-original draft preparation, C.-H.W. and T.-W.C.; writing-review and editing, C.-H.W. and T.-W.C.; supervision, T.-W.C.; C.-H.H. and Y.-F.L.; project administration, C.-H.H.; funding acquisition, T.-W.C.; C.-H.H. and Y.-F.L. All authors have read and agreed to the published version of the manuscript.

Funding: This research was funded by the Ministry of Education, Taiwan.

Acknowledgments: The authors appreciate the financial support from the "Research Center of Energy Conservation for New Generation of Residential, Commercial, and Industrial Sectors" from The Featured Areas Research Center Program within the framework of the Higher Education Sprout Project by the Ministry of Education (MOE) in Taiwan.

Conflicts of Interest: The authors declare no conflict of interest.

\section{References}

1. NASA Global Climate Change, Vital Sign of the Planet. Available online: https://climate.nasa.gov/vitalsigns/global-temperature/ (accessed on 3 August 2019).

2. Cui, Y.; Yan, D.; Hong, T.; Ma, J. Temporal and spatial characteristics of the urban heat island in Beijing and the impact on building design and energy performance. Energy 2017, 130, 286-297. [CrossRef]

3. Yang, Q.; Huang, X.; Tang, Q. The footprint of urban heat island effect in 302 Chinese cities: Temporal trends and associated factors. Sci. Total Environ. 2019, 655, 652-662. [CrossRef] [PubMed]

4. Ali, S.; Ehsan, S. Daily variation of urban heat island effect and its correlations to urban greenery: A case study of Adelaide. Front. Archit. Res. 2017, 6, 529-538.

5. Aneesh, M.; Sumit, K.; Nivedita, K. Analysis of diurnal surface temperature variations for the assessment of surface urban heat island effect over Indian cities. Energy Build. 2018, 59, 271-295.

6. Kamruzzaman, M.; Deilami, K.; Yigitcanlar, T. Investigating the urban heat island effect of transit oriented development in Brisbane. J. Transp. Geogr. 2018, 66, 116-124. [CrossRef]

7. Li, Y.; Ren, T.; Kinney, L.P.; Joyner, A.; Zhang, W. Projecting future climate change impacts on heat-related mortality in large urban areas in China. Environ. Res. 2018, 163, 171-185. [CrossRef] [PubMed]

8. UN. Trends in Sustainable Development 2008-2009, United Nations publication, United Nations Division for Sustainable Development. Available online: https://sustainabledevelopment.un.org/index.php?page=view\& type $=400 \& n r=30 \&$ menu $=1572$ (accessed on 1 May 2020).

9. Gentle, A.R.; Smith, G.B. Radiative heat pumping from the earth using surface phonon resonant nanoparticles. Nano Lett. 2010, 10, 373-379. [CrossRef] 
10. Fan, S.; Raman, A. Metamaterials for radiative sky cooling. Natl. Sci. Rev. 2018, 5, 132-133. [CrossRef]

11. Kim, H.H. Urban heat island. Int. J. Remote Sens. 1992, 13, 2319-2336. [CrossRef]

12. Argiriou, A.; Santamouris, M.; Balaras, C.; Jeter, S. Potentialof Radiative Cooling in Southern Eorope. Int. J. Solar Energy 1992, 13, 189-203. [CrossRef]

13. Geetha, N.B.; Velraj, R. Passive cooling methods for energy efficient buildings with and without thermal energy storage-A review. Energy Educ. Sci. Technol. Part A Energy Sci. Res. 2012, 29, 913-946.

14. Karam, M.A.; Mazran, I.; Abdul, M.A.R. Passive cooling techniques through reflective and radiative roofs in tropical houses in Southeast Asia: A literature review. Front. Archit. Res. 2014, 3, 283-297.

15. Li, N.; Wang, J.F.; Liu, D.F.; Huang, X.; Xu, Z.K.; Zhang, C.Y.; Zhang, Z.J.; Zhong, M.F. Selective spectral Optical properties and structure of aluminum phosphate for daytime passive radiative cooling application. Solar Energy Mater. Solar Cells 2019, 194, 103-110. [CrossRef]

16. Zhai, Y.; Ma, Y.; David, S.N.; Zhao, D.; Lou, R.; Tan, G. Scalable-manufactured randomized glass-polymer hybrid metamaterial for daytime radiative cooling. Science 2017, 355, 1062-1066. [CrossRef]

17. Zhang, Z.; Liu, D.; Xia, Z. Preparation of silica thin film by hot pressing process for passive radiative cooling. In Proceedings of the 10th International Conference on Thin Film Physics and Applications, Qingdao, China, 8 July 2019.

18. Bao, H.; Yan, C.; Wang, B.; Fang, X.; Zhao, C.Y.; Ruan, X.L. Double-layer nanoparticle-based coatings for efficient terrestrial radiative cooling. Solar Energy Mater. Solar Cells 2017, 168, 78-84. [CrossRef]

19. Papasavva, S.; Kia, S.; Claya, J.; Gunther, R. Characterization of automotive paints: An environmental impact analysis. Prog. Org. Coat. 2001, 43, 193-206. [CrossRef]

20. Gaikwad, M.S.; Gite, V.V.; Mahulikar, P.P.; Hundiwale, D.G.; Yemul, O.S. Eco-friendly polyurethane coatings from cottonseed and karanja oil. Prog. Org. Coat. 2015, 86, 164-172. [CrossRef]

21. Zoubi, W.A.; Ko, Y.G. A novel strategy to modify the surface of plasma electrolysis produced inorganic coatings for fabricating organic@functional binding agents@inorganic materials. J. Alloys Compd. 2019, 776, 1025-1028. [CrossRef]

22. Pehkonen, S.O.; Yuan, S.J. Chapter 7-The Inorganic Film Coatings for Corrosion Protection. Interface Sci. Technol. 2018, 23, 185-255.

23. Zhang, B.; Xu, G.; Liu, C.; Tan, S.; Xu, C.; Zhang, Y.; Zhang, J. Low infrared emissivity of the Cr39Ni7C/inorganic silicate coatings with excellent heat-resistant. Infrared Phys. Technol. 2018, 92, 234-239. [CrossRef]

24. Li, Y.C.; Liu, Y.Z.; Huang, Y.G.; Wang, W.X. Far-Infrared Radioactive Material and Manufacturing Method. China Patent CN103361450A. 2016. Available online: https://patents.google.com/patent/CN103361450A/en (accessed on 1 May 2020).

25. Lan, Y.; Liu, Q.; Meng, F.; Niu, D.; Zhao, H. Optimization of magnetic separation process for iron recovery from steel slag. J. Iron Steel Res. Int. 2017, 24, 165-170. [CrossRef]

26. Chen, S.H.; Wang, X.X.; Nie, G.D.; Liu, Q.; Sui, J.X.; Song, C.; Zhu, J.W.; Fu, J.; Zhang, J.C.; Yan, X.; et al. Infrared cooling properties of cordierite. Chin. Phys. B 2019, 28, 064401. [CrossRef]

27. Lobanov, L.M.; Ustinov, A.I.; Volkov, V.S.; Mokhniuk, A.A.; Telichko, V.A.; Demchenkov, S.A.A. A1/TiO2 bilayer coatings for space applications: Mechanical and thermoradiation properties. Thin Solid Films 2018, 668, 30-37. [CrossRef]

28. Wu, C.H. The Development of Geopolymeric Passive Radiative Cooling Coating. Master's Thesis, Institute of Mineral Resources Engineering, National Taipei University of Technology, Taipei, Taiwan, 2020.

29. Cai, M.F.; Liang, Y.H.; Nie, J.H.; Yin, Y.C.; Ju, M.Q.; Zhang, Q.X. Colloidal silica-bonded MgO-CaO hot gunning mixes: Characterization of physical properties, microstructure and gunning performance. Ceram. Int. 2019, 45, 22426-22431. [CrossRef]

30. Japanese Standards Association. Method of Measuring Spectral Emissivity of Ceramic Radiating Materials For Infrared Heaters By Using FTIR, JIS R 1801. 2002. Available online: https://infostore.saiglobal.com/en-us/ standards/jis-r-1801-2002-823722/ (accessed on 20 March 2002).

31. Jeong, S.Y.; Tso, C.Y.; Ha, J.Y.; Wong, Y.M.; Chao, C.Y.H.; Huang, B.L.; Qiu, H.H. Field investigation of a photonic multi-layered $\mathrm{TiO} 2$ passive radiative cooler in sub-tropical climate. Renew. Energy 2020, 146, 44-55. [CrossRef]

32. Bowers, S.A.; Hanks, R.J. Reflection of radiant energy from soils. Soil Sci. 1965, 100, 130-138. [CrossRef]

33. Kirchhoff, G.I. On the relation between the radiating and absorbing powers of different bodies for light and heat, The London. Edinb. Dublin Philos. Mag. J. Sci. 1860, 20, 1-21. [CrossRef] 
34. Committee for Conformity Assessment of Accreditation and Certification on Functional and Technical Textiles, 2007, Specified Requirements of Far Infrared Textiles, Taiwan. Available online: https://www.ftts. org.tw/images/019e.pdf (accessed on 26 December 2008).

35. Kljajević, L.M.; Nenadović, S.S.; Nenadović, M.T.; Bundaleski, N.K.; Todorović, B.Ž.; Pavlović, V.B.; Rakočević, Z.L. Structural and chemical properties of thermally treated geopolymer samples. Ceram. Int. 2017, 43, 6700-6708. [CrossRef]

36. Vidal, L.; Joussein, E.; Colas, M.; Cornette, J.; Sanz, J.; Sobrados, I.; Gelet, J.L.; Absi, J.; Rossignol, S. Controlling the reactivity of silicate solutions: A FTIR, Raman and NMR study. Colloids Surfaces A Physicochem. Eng. Asp. 2016, 503, 101-109. [CrossRef]

37. Pareek, S.; Kashima, H.; Maruyama, I.; Araki, Y. Adhesion characteristics of geopolymer mortar to concrete and rebars. Int. Conf. Sustain. Civil Eng. Struct. Constr. Mater. 2019, 258, 01012. [CrossRef]

(C) 2020 by the authors. Licensee MDPI, Basel, Switzerland. This article is an open access article distributed under the terms and conditions of the Creative Commons Attribution (CC BY) license (http://creativecommons.org/licenses/by/4.0/). 